\title{
AN ADDRESS BY THE HONOURABLE MR. JUSTICE I. C. RAND TO THE ALBERTA SECTION OF THE CANADIAN BAR ASSOCIATION*
}

This brings me to a few ideas I would like to express to you. I know you will acquit me of pretentiousness; but I think their matter is something that should be stressed. They are some of the conclusions I have drawn from my experience, and I feel somewhat at liberty to express them here in this province where I was introduced to our profession, to which I look back with a tinge of disappointment that I was unable to live out the years within its life, and where vigour and openness of mind which I know to be possessed by Albertans will not be closed against them.

That small local bar in Medicine Hat suggested what I then did and do now regard as desirable qualities of a barrister-an intellectual cultivation of broad dimensions, an intense interest in and a lively curiosity about politics, literature, science, the arts and the field of knowledge generally. Let me for a few moments elaborate that conception.

This hall now represents, seated before me, the beauty and, if I may so call them, the "legality" of Alberta. I should be silenced with awe as this scene bears down upon me were I not under a bounden duty, imposed upon me by your most generous selves, to speak, with what effect and agreeableness the Fates only can foresee. These ladies before me share the distinctions, whatever they may be, of a professional class of high order. Lawyers are professionals in the art of social adjustments by law; law cannot reach all human relations but most of the serious conflicts come within its range. Its importance, expanding as social bodies increase in population and their lives become more complex, is seen when we realize how self-conscious the world has become today, how the entire human family is in ferment, how Western ideas of self-government have become implanted in the minds of those who have never known it, and how thunderous are the tones being trumpeted everywhere demanding peace, equality, order and security.

Lawyers in Canada are the heirs of a great tradition formed and modelled over centuries by men of intellectual stature and insight. As our social attitudes and assumptions change-and many of them have gone through a process of transformation, some beyond recognition-it is becoming more and more evident that in the matrix of social fact the rules for the reconciliation of impacts and clashes between man and man must be formulated. In the transformation from a relatively static to a dynamic principle animating a society in turbulence and revolutionary thinking, the relativity of science finds its reflection in the resulting social relations and the laws pertinent to them. Absolutes which for centuries have been accepted unquestioningly are today

*This address was delivered at the Palliser Hotel, Calgary Alberta, January 28, 1959. 
disintegrating. The new basic assumptions have not yet clearly been formulated and we are in that state of transition in which conscious planning for the next era of humanity's life has not only become a necessity but is demanding the exercise of human resources which will tax the utmost powers of man's intellect to supply.

The natural wealth of this land and the capacities of its people mark it out to play a role of world significance. It is looked upon now as exemplifying some of the admired characteristics of democracy: sobriety in action and opinion, integrity in undertakings, strength and endurance, fairness and objectivity; these, I think, have been credited to us by world observers.

With such a people and such prospects of world influence, the magnitude of the task that faces Canadian lawyers is seen in dim outline. Its demands extend to deep understanding of the dominant determinants of social action of today, and, so far as we can foresee them, the ultimate recognitions of tomorrow; these can be reached and given expression only by unreserved effort.

The supreme accomplishment in the life of a lawyer is the production of a mind that can orient itself to any set of assumptions and work its way to their social consequences. He must be able to appreciate every element in a situation, to be an empiricist whose judgments are the product of attributing value to the significant factors in it. This calls for more scholarship, more realistic understanding of social facts in widening perspectives and broadening backgrounds, deeper appreciation of new attitudes, assumptions, needs and demands of Man that will emerge from these tremendous changes.

To balance the individual interest against the community interest is a vital part of the intensifying problem: to preserve, liberate and give scope for the expansion of new human energies, and at the same time consolidate the social unity. I have in mind chiefly the equipment of those lawyers who, in the future, will become the magistrates of the land and whose burden it will be to weave the fabric of our jurisprudence.

In the field of law we are the makers of our own destiny; we have none but ourselves to look to for our solutions. We must agree that at the moment we are not entitled to claim equality with the scholarship in jurisprudence of Europe or the United States nor have we as yet reached their dimensions in imaginative and original thinking. The progress in this function in the United States shows a massive accomplishment, and we must set out to emulate as never before that achievement. We must, on a wider scale, do our own thinking-out of new problems and express it in our own idiom. The tendency of the past has been first to put ourselves the question: "what are the authorities for which we looked largely to England?" That was followed by exposition in terms of the thinking of others. I would reverse the method; the first step should be to attack the problem directly and by thorough analysis to expose the operating elements; with the application of legal rules, principles, and other traditional means, we should move to conclusions; then let the call for authorities be made. This is said to have been exemplifiedwhether truly so or not, I cannot say, but that does not weaken its illustrative 
force-on the U.S. Supreme Court by Chief Justice Marshall in reaching a solution in the manner suggested and in then calling upon Justice Storey, a most learned jurist, to furnish the precedents. It is a mode of functioning not only for judges but for counsel as well. A weakness in the higher appeal courts today is not infrequently the inadequacy in what is presented them; in too many arguments there is not being displayed that command of the relevant considerations which leads directly to the ultimate issues.

In economic and scientific achievements, the establishment of standards in them, and in the technique and efficiency required, we seem to be well up with the leaders and our course so far is not unsatisfactory. In our professional field of law we must call upon our pride to stimulate us to a new conception of responsibility and to new resolution, and to look upon the goal set as one which, as an essential of our national role, must be attained.

Minds cultivated in the humanities and the other fields of knowledge, minds flexible, mobile, adaptable, resourceful, well endowed with the instruments of intellectual action and saturated with our guiding traditions, these are the accomplishments to be sought. The insistent elements today are creativity in new circumstances, clarity and depth of insights into the past and the evolving community life, tested judgment in giving significance and weight to the various factors.

This portrays no easy task for any group of men. I remember many years ago listening to Sir John Simon in Ottawa speaking to the Convention of the Canadian Bar Association on the art of advocacy. For success in that role he laid down three rules to be observed: the first was unremitting toil, the second was unremitting toil and the third was unremitting toil. There is nothing in that to cause alarm. There is vast compensation in that toil, one of the finest of all intellectual adventures. In this glittering brilliance of the products of materialism which surround us here in Calgary tonight, in this dazzling display of what western civilization has succeeded in fabricating, let us remember our courts and locally your auditorium. What do they symbolize? Surely nothing less than permanent values, law and art, twin necessities at all times but never so much as today. Petroleum will in time burn out to its last flicker: soon we shall probably be piping heat and energy from the sun; are we, for that reason, to become sun worshippers? Why should we not rather give equivalent homage to the intellectual power that broke through the darkness of ignorance and enabled that mastery to be attained? The demand on western life today, the demand of enlightened peoples, is the mastery of life through understanding. To no group of professionals is that aim more appropriate and its pursuit of higher importance than to the leaders and fellows of the bar of this country.

Again let me thank you for the pleasure and the privilege of being here this evening. It is a stimulating association which Mrs. Rand and I, if spared, will long remember. The word "great" can fairly be applied to this province, but in the last analysis greatness, rightly understood, is an attribute of men and women and not of things. This is also a great country, Canada, and we cannot afford in any area of its national life to let it down. 
Although, with my friends Stewart Blanchard and Gilbert Blackstock, I must, of course, maintain that ours was the golden era, I can admit that you, the new generations, are threatening that eminence; in fact with the help of all these embodiments of charm and vivacity who have done me the honour of listening to these remarks, we should be disappointed if this period does not surpass it, and so we are happily prepared in confidence to leave the field to you and your successors. 